\title{
SOLUSI INTERVENSI KEMANUSIAAN SEBAGAI PENYELESAIAN KONFLIK YANG TERJADI PASCA KUDETA PRESIDEN MURSI DI MESIR
}

\author{
Dodik Setiawan Nur Heriyanto' \\ Fakultas Hukum Universitas Islam Indonesia \\ Email : dodiksetiawan@gmail.com
}

\begin{abstract}
Mohamed Morsi was became Egypt's first democratically elected president based on Presidential election held in 2012. However, he has been ousted from Presidential office just over one year into his presidency. President Morsi and Muslim Brotherhood leaders were arrested. Egypt's Minister of Defense was appointed Adly Mansour as interim president until an election could take place based on the announcement of Egypt's Minister of Defense. This announcement caused several days of bloodshed, since around 600 people were killed in clashes as police broke up protest camps of Morsi supporters. This condition raised international protest and urged immediate humanitarian intervention to end turmoil and save most Egyptians. This paper will analyzed whether or not the need of humanitarian intervention give an effective solution for Egypt's crises.
\end{abstract}

\section{Keywords : humanitarian, resolution, Egypt}

\section{PENDAHULUAN}

Muhamad Mursi merupakan seorang politisi Mesir yang terpilih sebagai Presiden kelima Mesir pada Juni 2013. ${ }^{2}$ Mursi tercatat sebagai Presiden Mesir pertama kali yang dipilih secara langsung oleh rakyat Mesir ${ }^{3}$ meskipun Presiden Mesir sebelumnya (Husni Mubarak) juga dipilih secara demokratis namun dilakukan dengan penuh kecurangan. ${ }^{4}$

Setelah pemerintahan Mursi berjalan selama satu tahun, banyak terjadi kebijakan yang menimbulkan protes rakyat. Kebijakan tersebut dinilai inkonstitusional ${ }^{5}$, lebih menguntungkan kelompok Ikhwanul Muslimin ${ }^{6}$, memperburuk kondisi sektor ekonomi Mesir ${ }^{7}$, dan tidak menjunjung tinggi nilai demokrasi ${ }^{8}$.

1 Penulis adalah Dosen Tetap Fakultas Hukum Universitas Islam Indonesia.

2 Mursi mengalahkan Mantan JenderalAhmad Shafiq dengan selisih 3,5 persen pemilih atau sekitar 900.000 pemilih. Islamist Joy as Morsi Morsi Elected Egypt President. Diakses melalui http://www.reuters.com/article/2012/06/24/us-egypt-election-idUSBRE85G01U20120624 pada tanggal 21 Agustus 2013.

3 Named Egypt's Winner, /slamist Makes History. Diakses melalui http://www.nytimes.com/2012/06/25/world/middleeast/mohamedmorsi-of-muslim-brotherhood-declared-as-egypts-president.html?pagewanted=all pada tanggal 21 Agustus 2013.

4 Banyak kalangan di Mesir menganggap bahwa pemilihan umum yang diselenggarakan dengan banyak kecurangan dan tidak sah. 'Vote Rigging' Mars Egypt Election. Diakses melalui http://www.aljazeera.com/news/middleeast/2010/11/2010112844850659269.html pada tanggal 21 Agustus 2013.

5 Presiden Mursi mengeluarkan Dekrit Presiden pada tanggal 22 November 2012 dengan substansi mengganti Jaksa Agung yang lama dengan yang baru dan membuat kebijakan baru: Jaksa Agung dipilih oleh Presiden selama periode jabatan empat tahun. Dekrit ini dinilai justru akan menjadikan Mursi kebal terhadap hukum. Timeline of Morsi and Judiciary: One Year in Power. Diakses melalui http://wun. dailynewsegypt.com/2013/06/29/timeline-of-morsi-and-the-judiciary-one-year-in-power/ pada tanggal 21 Agustus 2013.

6 Selama kepemimpinan Mursi, Ikhwanul Muslimin menguasai 10 (sepuluh) dari total 35 (tigapuluh lima) kursi pemerintahan. Pihak oposisi Mesir menilai Mursi sangat berambisi untuk memperkuat kedudukan Ikhwanul Muslimin pada pos-pos pemerintahan daripada menekankan prinsip pemerintahan yang baik dan adil. Mohammed Morsi reshuffles Egypt's Cabinet, 3 posts go to Muslim Brotherhood. Diakses pada http://wuw.mcclatchydc.com/2013/05/07/190613/mohammed-morsi-reshuffles-egypts.html\#.UhTUiZWBLOE pada tanggal 21 Agustus 2013.

7 Banyak kalangan menilai periode satu tahun pemerintahan Mursi membawa dampak buruk bagi ekonomi Mesir. Masyarakat Mesir merasakan harga kebutuhan pokok meningkat dan bahkan krisis bahan bakar. Hazem El-Beblawy : Morsi's overall economic performance was weak. Diakses melalui http://www.dailynewsegypt.com/2013/06/29/hazem-el-beblawy-morsis-overall-economic-performance-was-weak/ pada tanggal 21 Agustus 2013.

8 Salah satu contoh pelanggaran nilai demokrasi rezim Mursi: Pengekangan terhadap pergerakan jurnalis dan media di Mesir selama pemerintahan Mursi melanggar kebebasan pers. One Year Into Mohamed Morsi's Term Manifold Abuses And The Systematic Undermining of The Rule of Law. Diakses melalui http://www.cihrs.org/?p=6849\&lang=en pada tanggal 21 Agustus 2013. 
Cidera kebijakan selama pemerintahan Mursi menyebabkan hujan protes dari rakyat Mesir. Sebagai akibat dari protes yang tak terbendung dan membesarnya aksi demonstrasi menentang Mursi, Panglima Angkatan Bersenjata Mesir, Jenderal Abdul Fatah al-Sisi, mengumumkan pemberhentian Mursi dan mengangkat Ketua Mahkamah Konstitusi Mesir Adli Mansour ${ }^{9}$ sebagai presiden sementara sampai pemilihan presiden berikutnya berlangsung. Abdul Fatah al-Sisi pada saat yang sama juga membekukan konstitusi Mesir ${ }^{10}$ yang telah banyak tidak sesuai dengan keinginan rakyat.

Dalam perkembangannya pasca kudeta, terjadi konflik antara pendukung Mursi dan penentang Mursi. Konflik-pun mulai beragam: terjadi bentrokan fisik antara massa pro-Mursi dan penentang Mursi yang menyebabkan beberapa korban jiwa dan penangkapan massa pendukung Mursi yang sebagian berasal dari Ikhwanun Muslimin. ${ }^{11}$ Mursi dan beberapa pendukung loyalis-nya dikenai tahanan rumah. ${ }^{12}$ Bahkan tidak hanya sampai disitu saja, pemberitaan terkait tewasnya 36 tahanan pendukung Mursi karena ditembak oleh kawanan bersenjata ${ }^{13}$ memicu protes internasional ${ }^{14}$.

Melihat situasi Mesir yang semakin mencekam, masyarakat internasional mendesak untuk dilakukannya upaya yang dianggap perlu untuk mencegah korban yang lebih banyak di Mesir. Secara khusus Turki mendesak masyarakat internasional khususnya Dewan Keamanan PBB (DK PBB) dan Liga Arab untuk segera mengakhiri konflik yang terjadi di Mesir. ${ }^{15}$ Beberapa kalangan bahkan mendesak perlunya intervensi kemanusiaan (humanitarian intervention) ${ }^{16}$ dalam situasi Mesir yang semakin bergejolak.

\section{DILEMA PELAKSANAAN INTERVENSI HUMANITER}

Isu intervensi humaniter selalu menjadi perdebatan yang belum selesai baik dalam hukum dan hubungan internasional. ${ }^{17} \mathrm{Di}$ satu sisi, hukum internasional menjamin hak suatu negara untuk mengintervensi negara lain dalam hal pencegahan pelanggaran hak asasi manusia (HAM) secara masif. Sedangkan, disisi lain intervensi humaniter bertentangan dengan prinsip kedaulatan negara (state sovereignty) dan prinsip non-intervensi (non-intervention).

Hukum internasional pada dasarnya menjamin negara memiliki kedaulatan untuk mengurusi urusan rumah tangganya sendiri. Prinsip kedaulatan tidak memperkenankan suatu negara campur tangan baik urusan internal maupun eksternal negara lain. Prinsip ini pun sudah jelas diatur dalam Pasal 2 ayat (4) Piagam PBB bahwa 'setiap negara anggota PBB wajib menjauhkan diri untuk menggunakan kekerasan (use of force) terhadap integritas wilayah atau-kemerdekaan politik suatu negara lain atau dengan cara apapun yang bertentangan dengan tujuan PBB'. ${ }^{18}$ Sejalan

\footnotetext{
9 Egypt's New Interim President: Judge Adly Mansour. Diakses melalui http://english.ahram.org.eg/NewsContent/1/0/75638/Egypt/0/ Egypts-new-interim-president-Judge-Adly-Mansour.aspx pada tanggal 21 Agustus 2013.

${ }^{10}$ Egypt Army Chief Ousts Morsi. Diakses melalui http://www.foxnews.com/world/2013/07/03/egypt-army-chief-ousts-morsi/ pada tanggal 21 Agustus 2013.

11 Situasi Mesir Mencekam, 4 Pendukung Mursi Tewas Bentrok Dengan Polisi. Diakses melalui http://news.detik.com/read/2013/07/04/0 51742/2292088/1148/situasi-mesir-mencekam-4-pendukung-morsi-tewas-bentrok-dengan-polisi pada tanggal 21 Agustus 2013.

12 Ikhwanul Muslimin: Mursi Jadi Tahanan Rumah. Diakses melalui http://www.republika.co.id/berita/internasional/global/13/07/04/ mpdywc-ikhwanul-muslimin-mursi-jadi-tahanan-rumah pada tanggal 21 Agustus 2013.

${ }^{13}$ Egypt: 36 Killed in Prison Truck Escape Attempt. Diakses melalui http://abcnews.go.com/International/wireStory/egypt-edge-stormingprotester-mosque-19992957 pada tanggal 21 Agustus 2013.

14 Turki mengecam diamnya Organisasi Internasional seperti PBB dan Uni Eropa yang diam terhadap krisis Mesir. Turkey PM Condemns Inaction On Egypt Crisis. Diakses melalui http://www.channelnewsasia.com/news/world/turkey-pm-condemns/780860.html pada tanggal 21 Agustus 2013. Egypt: Call For Daily Protests As Dozens Die. Diakses melalui http://news.sky.com/story/1129271/egypt-call-for-daily-protestsas-dozens-die pada tanggal 21 Agustus 2013.

15 The Bloody Intervention In Egypt Was Condemned In A Statement Released By Prime Ministry of Turkey. Diakses melalui http:// www.mfa.gov.tr/the-bloody-intervention-in-egypt-was-condemned-in-a-statement-released-by-prime-ministry-of-turkey.en.mfa pada tanggal 21 Agustus 2013.

${ }^{16}$ Clovis Maksoud berpandangan bahwa negara-negara Arab dan masyarakat internasional harus segera berupaya untuk melakukan tindakan intervensi kemanusiaan di Mesir. Egypt Deaths Call For Action. Diakses melalui http://news.sky.com/story/1129271/egypt-call-fordaily-protests-as-dozens-die pada tanggal 21 Agustus 2013.

17 J. L. Holzgreve dan Robert O. Keohane (ed.) Humanitarian Intervention: Ethical, Legal, and Political Dilemmas. UK: Cambridge University Press. 2003. Him.1.

18 Piagam Perserikatan Bangsa-Bangsa 1945 (selanjutnya disebut Piagam PBB). Pasal 2 (4). Dalam Pasal 2 (1) Piagam PBB juga
} 
dengan hal tersebut, dalam Pasal 2 ayat (1) Piagam PBB juga memuat konsep non-intervensi dimana PBB dilarang mengintervensi yurisdiksi domestik suatu negara. ${ }^{19}$

Suatu negara mungkin saja menggunakan kedaulatan yang dimilikinya untuk melakukan pembunuhan masif warga negaranya. Kasus pelanggaran HAM yang seringkali didiamkan begitu saja menjadikan prinsip kedaulatan dan non-intervensi dapat dikecualikan. Berdasarkan praktek internasional, suatu negara dimungkinkan untuk mengintervensi negara lain dengan alasan kemanusiaan. Dalam Traktat London atau Treaty of London (1827), baik Inggris, Perancis, dan Rusia berkeputusan untuk mengintervensi Yunani dengan jalan membantu Yunani melawan Dinasti Ottoman (Turki)..$^{20}$ Intervensi yang dilakukan ketiga sekutu Eropa kepada Yunani tersebut secara nyata dan efektif membantu Yunani untuk merebut kemerdekaan.

Praktek intervensi juga tercatat dalam Perang Kemerdekaan Kuba atau Cuban War of Independence (1895-1898), Amerika mengintervensi Kuba dengan mengirimkan bantuan militer untuk berperang melawan Spanyol. ${ }^{21}$ Bantuan Amerika tersebut berujung pada kekalahan Spanyol dan kemudahan rakyat Kuba untuk merdeka. Sebagai bentuk kekecewaan Spanyol atas intervensi Amerika kepada Kuba, Spanyol kemudian menyerang Amerika dan dikenal dengan Spanish-American War (1898). ${ }^{22}$

Praktek intervensi kemanusiaan semakin banyak dilakukan negara-negara khususnya pada era perang dingin. Salah satu kasus yang sering menjadi bahasan adalah intervensi militer India di Pakistan Timur yang kemudian merdeka dan berganti nama menjadi Bangladesh. India terpaksa mengintervensi Pakistan Timur dan membantunya untuk merdeka ${ }^{23}$ karena militer Pakistan telah melakukan pembantaian yang khususnya ditujukan pada suku Bengali yang beragama hindu dan mengakibatkan kurang lebih tiga juta penduduk terbunuh dan lebih dari empat ratus ribu wanita diperkosa. ${ }^{24}$ Namun, intervensi yang dilakukan India juga dianggap sebagai wujud pembelaan diri (self defense) karena merasa terancam ${ }^{25}$ atas kebijakan keji yang dilakukan Pakistan.

Pelaksanaan intervensi humaniter memang menjadi dilemma tersendiri karena bertentangan dengan kedaulatan negara dan prinsip non-intervensi. Meskipun dalam Piagam PBB secara jelas melarang melakukan intervensi terhadap kedaulatan negara, namun dalam perkembangannya boleh saja melakukan intervensi kemanusiaan dalam keadaan yang sangat eksepsional: kewajiban untuk melindungi semua warga negara dan menjamin penegakan HAM di dunia.

\section{KEABSAHAN INTERVENSI HUMANITER}

Dilema pelaksanaan intervensi humaniter baik dari segi normatif maupun praktek hubungan internasionaldisambutdengan perbedaan pendapatdariparaahlihukuminternasional. lan Brownlie berpendapat bahwa intervensi humaniter akan membuka pelanggaran yang lebih

\footnotetext{
mengatur berdirinya PBB didasarkan atas asas persamaan kedaulatan semua negara anggotanya (The Organisation is based on the principle of the sovereign equality of all its Members).

${ }^{19}$ Ibid. Pasal 2 (1).

20 Treaty Between Great Britain, France, and Russia, For The Pacification Of Greece. (London, July 6, 1827). Diakses melalui http://www. fordham.edu/halsall/mod/1827gktreaty.asp pada tanggal 21 Agustus 2013.

${ }^{21}$ Philip Brenner. From Confrontation to Negotiation. United States of America: Westview Press. 1988. Him. 7.

22 Benjamin R. Beede. The War of 1898, and U.S. interventions, 1898-1934: an encyclopedia. New York \& London: Garland Publishing Inc. 1994. Him.120-148.

${ }^{23}$ Intervensi India berlangsung saat terjadinya Bangladesh Liberation War (Perang Kemerdekaan Bangladesh) tahun 1971. Perang berlangsung selama kurang lebih Sembilan bulan antara India dan Pakistan Timur melawan Pakistan Barat.

${ }^{24}$ Bruce O. Riedel. Deadly embrace: Pakistan, America, And The Future Of The Global Jihad. Washington: Brookings Institution Press. 2011. Him.10.

${ }^{25}$ Onkar Marwah. "India's Military Intervention in East Pakistan: 1971-1972". Modern Asian Studies Vol. 13, No. 4 (1979). Him. 549.
} 
luas. ${ }^{26}$ Jika intervensi humaniter dianggap sah (legal), negara yang memiliki kekuatan besar akan dengan mudah menggulingkan kekuasaan pemerintahan suatu negara berdasar alasan kuat negara tersebut tidak responsif terhadap keinginan internasional. ${ }^{27}$

Namun, sebagian ahli juga menganggap intervensi kemanusiaan dapat dibenarkan untuk dilaksanakan selama menghormati kaidah-kaidah hukum dan kebiasaan internasional. Sejauh ini terdapat perkembangan konsep batasan sejauh mana intervensi kemanusiaan dapat dilaksanakan. Batasan tersebut antara lain:

a. Doktrin international responsibility to protect

Rezim HAM memberikan kewajiban setiap negara untuk menjamin perlindungan HAM bagi setiap warga negara di wilayahnya. Kewajiban ini lebih dikenal dengan doktrin "responsibility to protect". Pertanyaan yang muncul kemudian adalah apakah suatu negara juga memiliki kewajiban untuk menegakkan HAM di negara lain? Menurut laporan International Commission on Intervention and State Sovereignty (ICISS), bilamana suatu negara tidakmau atau tidakmampu mencegah atau melakukan tindakan yang menyebabkan luka fisik atau kematian penduduknya, maka prinsip non-intervensi dapat disimpangi dan menjadi beban kewajiban internasional untuk melakukan pencegahan dan melindunginya (international responsibility to protect). ${ }^{28}$ Laporan ICISS ${ }^{29}$ memberikan kejelasan apabila suatu negara memperlakukan warga negaranya dengan kejam dan melanggar HAM, maka hak kedaulatan negara tersebut hilang dan masyarakat internasional memiliki kewajiban moral untuk mengintervensi negara tersebut.

Kewajiban masyarakat internasional untuk menjamin perlindungan HAM dengan jalan mengintervensi kedaulatan suatu negara dapat dilakukan selama memenuhi parameter berikut ini: $:^{30}$

- Telah terjadi pelanggaran HAM serius

Penegakan HAM sangat penting diselenggarakan dan secara jelas diatur dalam Pembukaan Piagam $\mathrm{PBB}^{31}$, Pasal $1(3)^{32}, 55^{33}$, dan $56^{34}$. Selain itu, perlindungan HAM juga diatur dalam Konvensi tentang Pencegahan dan Hukuman Bagi Tindak Kejahatan Genosida 1948, Deklarasi HAM PBB 1948, Statuta Roma 1998, dan perjanjian internasional terkait lainnya. Rezim pengaturan HAM saat ini berimplikasi batas wilayah suatu negara bukan menjadi penghalang dalam pelaksanaan dan perlindungan HAM. Dari keseluruhan pengaturan tersebut, kedaulatan negara menjadi limitatif: negara tidak diperkenankan berlaku sewenang-wenang terhadap warga negaranya. Sehingga justifikasi paling kuat untuk melakukan tindakan intervensi kemanusiaan mendasarkan

\footnotetext{
26 lan Brownlie. "Humanitarian Intervention" dalam Norton John Moore, et.al. Law and Civil War in Modern World. Baltimore: John Hopkins University Press. 1974. Him. 224.

27 Oscar Scachter. "The Legality of Pro-Democratic Invasion", 78 American Journal of International Law. 1984. Him. 649. Dikutip dari J.L.Holzgreve dan Robert O. Keohane (ed.) Op. Cit. Him. 24.

${ }^{28}$ International Commission on Intervention and State Sovereignty Report, HIm.xi. Diakses melalui http://www.iciss-ciise.gc.ca/pdfl Commission- Report.pdf pada tanggal 22 Agustus 2013.

29 Laporan ICISS ini juga diadopsi dalam KTT (World Summit) Majelis Umum PBB Tahun 2005.

${ }^{30}$ Penulis mencoba membuat suatu simpulan terkait batasan doktrin "international responsibility to protect" dengan mengambil intisari ragam pendapat para ahli.

${ }^{31}$ Dalam Pembukaan Piagam PBB disebutkan bahwa seluruh anggota PBB bertekad untuk meyakini adanya hak asasi dasar (to reaffirm faith in fundamental human rights, in the dignity and worth of the human person, in the equal rights of men and women and of nations large and small).

${ }^{32}$ Dalam Pasal 1 (3) Piagam PBB disebutkan tujuan berdirinya PBB salah satunya untuk meningkatkan upaya penghormatan terhadap HAM (.... in promoting and encouraging respect for human rights...)

${ }^{33}$ Dalam Pasal 55 disebutkan bahwa PBB berkewajiban untuk menghormati dan menjamin perlindungan HAM dan kebebasan dasar tanpa membedakan latar belakang ras, jenis kelamin, suku dan agama.

34 Seluruh anggota PBB dapat bekerja bersama-sama atau melalui kerjasama dengan organisasi lain untuk melaksanakan tujuan sebagaimana dimaksud pada Pasal 55 Piagam PBB.
} 
pada: kewajiban dan kebutuhan untuk melindungi HAM. ${ }^{35}$

Parameter pelanggaran HAM berat sudah diatur dalam Statuta Roma 1998. Dalam Pasal 5 Statuta Roma 1998 disebutkan tindak kejahatan yang termasuk "most serious crimes" antara lain: genosida, kejahatan terhadap kemanusiaan, kejahatan perang dan kejahatan agresi. ${ }^{36}$

Intervensi kemanusiaan untuk mencegah pelanggaran serius terhadap HAM sudah banyak dipraktekkan negara-negara: intervensi India di Pakistan Timur 1971, intervensi Vietnam di Kambodia 1978, intervensi Tanzania di Uganda 1979, Operasi Save Haven tahun 1991 bagi suku Kurdi di Iraq, Operasi Penyelamatan Somalia pada perang saudara tahun 1992-1993, Operasi Kosovo di Albania, dan lain sebagainya.

- Tidak dilakukan untuk tujuan atau kepentingan tertentu

Damrosch ${ }^{37}$ dan Julius Stone ${ }^{38}$ berpendapat bahwa intervensi humaniter tidak akan bertentangan dengan ketentuan Pasal 2 (4) Piagam PBB karena substansi pengaturan pasal tersebut mengarahkan pada pelarangan adanya penggunaan kekerasan untuk merebutkan kekuasaan atau wilayah suatu negara. Sehingga apabila intervensi humaniter dilakukan untuk tujuan selain sebagai upaya perlindungan HAM maka dapat dikatakan bahwa intervensi yang dilakukan tidak sah (ilegal).

b. Otorisasi DK PBB

Beberapa pandangan menyebutkan bahwa keabsahan intervensi humaniter dilakukan dengan berdasarkan ketentuan Bab VII Piagam PBB. Intervensi humaniter yang sah harus mendapatkan otorisasi dari DK PBB. Sebelum memberikan otorisasi DK PBB akan melakukan pencermatan ${ }^{39}$ apakah kondisi negara yang akan di intervensi mengancam perdamaian, melanggar perdamaian, atau telah terjadi tindakan agresi (threat to the peace, breach of the peace, or act of aggression) ${ }^{40}$. Apabila ternyata kondisi yang terjadi justru mengancam perdamaian dan keamanan dunia, maka DK PBB akan memberikan kewenangan suatu negara atau organ PBB atau organisasi internasional yang ditunjuk untuk melakukan intervensi.

Hanya intervensi yang direstui DK PBB lah yang dibenarkan menurut hukum internasional, sedangkan intervensi yang dilakukan secara unilateral atau kolektif oleh sejumlah negara tanpa otorisasi Dewan dianggap tidak sah dan bertentangan dengan hukum internasional dan ketentuan-ketentuan Piagam PBB. ${ }^{41}$ Sehingga otorisasi dari DK PBB menjadi syarat penting untuk memperkuat legalitas intervensi humaniter.

c. Doktrin just war

Doktrin just war memberikan justifikasi atau alasan pembenar untuk melakukan serangan terhadap negara lain selama serangan (perang) dilakukan secara adil. Doktrin ini memberikan batasan seperti apa intervensi boleh dilakukan, dan norma apa saja yang menjadi pedoman dalam melakukan intervensi secara benar. ${ }^{42}$

${ }^{35}$ D. J. Harris berpendapat bahwa intervensi dengan alasan kemanusiaan sangat dimungkingkan secara hukum (.... intervention in the interest of humanity is legally permissible). D. J. Harris. Cases and Materials on international Law. London: Sweet and Maxwell. 1991. HIm. 872.

${ }^{36}$ Rome Statute of the International Criminal Court (1998), Pasal 5.

${ }^{37}$ L. F. Damrosch (ed.) Enforcing Restraint: Collective Intervention in Internal Conficts. New York: Council on Foreign Relations. 1993. HIm. 219.

38 J.L.Holzgreve dan Robert O. Keohane (ed.) Op.Cit. Him. 37.

${ }^{39}$ Piagam PBB. Pasal 40.

40 ibid. Pasal 39.

${ }^{41}$ Boer Mauna. Hukum Internasional: Pengertian Peranan dan Fungsi dalam Era Dinamika Global. Edisi Kedua. Cetakan ke-4. Bandung: PT. Alumni. 2011. Him.653.

42 J. B. Elshtein. 'Just War and Humanitarian Intervention'. Ideas Vol. 8, No. 2 (2001). HIm.4. 
Selama intervensi humaniter dilakukan sebagai alasan yang benar dan dilakukan dengan cara yang benar maka tindakan intervensi tersebut boleh dilakukan. Peter Hough memberikan kriteria perang yang adil sebagai berikut:

- Just ad bellum: (a) must be waged by a sovereign authority; (b) must be a just cause for the war; self defence or the enforcement of human rights; (c) peaceful means of resolving the dispute must have been exhausted; (d) must be likely to succeed.

- Just in bello: (a) means used should be proportionate to the wrong being rectified; (b) unavoidable killing of non-combatants should be avoided; (c) wounded troops and prisoners of war should not be killed. ${ }^{43}$

Senada dengan uraian Peter Hough, intervensi kemanusiaan harus dilakukan dengan seadil-adilnya baik sebelum akan melakukan intervensi (just ad bellum) maupun pada pelaksanaan intervensi (just in bello). Pada saat sebelum melakukan intervensi, . perlu dipertimbangkan bahwa intervensi hanya dilakukan dalam kerangka pembelaan diri atau pelaksanaan HAM dan tindakan intervensi hanya dapat dilakukan bilamana semua seluruh upaya damai telah menemui jalan buntu. Sedangkan pada saat proses intervensi berlangsung, maka negara yang melakukan intervensi harus menjunjung tinggi minimum humanitarian standard (standar kemanusiaan minimum): adanya suatu perlindungan yang memadai terhadap manusia (human person). ${ }^{44}$

\section{EFEKTIVITAS INTERVENSI HUMANITER PADA KONFLIK MESIR}

Eskalasi konflik antara pendukung Mursi dan penentangnya di Mesir semakin meluas dan menambah jumlah korban khususnya warga Mesir yang tidak bersalah. Terlebih dari serangkaian fakta yang ada mengarahkan militer yang berkuasa saat ini menjadikan kelompok ikhwanul muslimin menjadi korban pembantaian. Kejadian ini tidak dapat dibiarkan begitu saja. Pembiaran konflik yang mengarah kepada pelanggaran HAM dapat menimbulkan ketidakpercayaan masyarakat internasional khususnya terhadap DK PBB.

Sejauh ini, belum ada upaya lanjut yang dilakukan PBB dalam menangani konflik di Mesir. DK PBB belum membuat resolusi untuk mengakhiri konflik di Mesir. Pada rapat terakhir, DK PBB hanya sebatas memberikan pernyataan bahwa konflik di Mesir harus segera diakhiri dan menyatakan simpati atas jatuhnya korban ${ }^{45}$, padahal konflik di Mesir semakin bergejolak. Bahkan Indonesia belum secara tegas dan nyata melakukan upaya untuk membantu perdamaian Mesir. ${ }^{46}$

Tindakan intervensi kemanusiaan memang merupakan upaya yang paling terakhir untuk dilaksanakan di Mesir. Masih banyak peluang diplomasi yang dapat diambil dalam melakukan perdamaian di Mesir meski sering tidak tercapai solusi. ${ }^{47}$ Namun, pelanggaran HAM yang dilakukan pasca kudeta tidak dapat dibiarkan begitu saja. Ada kewajiban masyarakat internasional untuk mencegah dan melindungi HAM di Mesir.

Berkaca dari kasus Suriah, tidak adanya intervensi humaniter menyebabkan pertikaian di Suriah semakin tidak terselesaikan. Penekanan diplomatik yang dilakukan berimbas tidak efektifnya upaya perdamaian yang dilakukan selama ini. Pelanggaran HAM justru meluas

\footnotetext{
${ }^{43}$ Peter Hough. Understanding Global Security. London: Routledge. 2004. HIm. 36.

44 Arlina Permanasari, et.al. Pengantar Hukum Humaniter. Jakarta: ICRC. 1999. Him.156.

${ }_{45}$ Egypt Authorizes Use of Live Ammunition Against Pro-Morsi Protesters. Diakses melalui http://articles.washingtonpost.com/2013-0815/world/41412007_1_mohamed-morsi-muslim-brotherhood-rabaa pada tanggal 22 Agustus 2013.

${ }^{46}$ Belum ada upaya nyata dari Pemerintah Indonesia untuk ikut andil mengupayakan perdamaian di Mesir. Padahal secara historis Mesir merupakan negara pertama yang memberi pengakuan bagi Indonesia. Konflik Mesir dan Indonesia. Diakses melalui http://www.republika. co.id/berita/jurnalisme-warga/wacana/13/07/30/mqqkyt-konflik-mesir-dan-indonesia pada tanggal 22 Agustus 2013.

47 Pemerintah Mesir sebut diplomasi gagal akhiri krisis. Diakses melalui http://www.radioaustralia.net.au/indonesian/2013-08-07/ pemerintah-mesir-sebut-diplomasi-gagal-akhiri-krisis/1172836 pada tanggal 22 Agustus 2013.
} 
dilakukan Rezim Assad salah satunya adalah tragedi HAM di kota Houla: pembantaian penduduk (sebagian besar korban berasal dari wanita dan anak-anak). ${ }^{48}$. DK PBB telah berusaha mengeluarkan resolusi yang mengecam dan menjatuhkan sanksi kepada Suriah, namun Rusia dan Cina menggunakan vetonya untuk rancangan resolusi tersebut meskipun substansi resolusi tidak menekankan upaya intervensi kemanusiaan. ${ }^{49}$

Intervensi kemanusiaan yang dilakukan oleh NATO di Libya justru terbilang efektif. Intervensi tersebut merupakan mandat dari Resolusi DK PBB 1973.50 NATO secara efektif mampu menyelesaikan konflik di Libya dan mencegah terjadinya pelanggaran HAM yang semakin meluas. Meskipun intervensi menuai kritik dari banyak pihak, intervensi tersebut dilakukan secara sah dan terbukti dapat menghentikan jumlah korban jiwa sebagai akibat pelanggaran HAM oleh rezim Ghadafi.

\section{PENUTUP}

Intervensi kemanusiaan sangat mendesak untuk dilaksanakan di Mesir untuk menghentikan pelanggaran HAM yang dilakukan pemerintahan interim kepada pendukung Mursi. Maka dari itu, dibutuhkan mandat dari DK PBB untukmelegalisasi intervensi kemanusiaan di Mesir. Tipologi konflik di Mesir yang berbeda dengan konflik di Libya dan Suriah menjadikan intervensi kemanusiaan tidak mudah dilakukan. Namun, intervensi tidak selalu menggunakan kekerasan melainkan dapat dilakukan untuk menengahi pertikaian antara penentang dan pendukung Mursi.

\section{DAFTAR PUSTAKA}

Beede, Benjamin R.. The War of 1898, and U.S. interventions, 1898-1934: an encyclopedia. New York \& London: Garland Publishing Inc. 1994

Brenner, Philip. From Confrontation to Negotiation. United States of America: Westview Press. 1988. HIm. 7.

Damrosch, L. F. (ed.) Enforcing Restraint: Collective Intervention in Internal Conflicts. New York: Council on Foreign Relations. 1993.

Egypt: 36 Killed in Prison Truck Escape Attempt. Diakses melalui http://abcnews.go.com/ International/wireStory/egypt-edge-storming-protester-mosque-19992957 pada tanggal 21 Agustus 2013.

Egypt Army Chief Ousts Morsi. Diakses melalui http://www.foxnews.com/world/2013/07/03/ egypt-army-chief-ousts-morsi/ pada tanggal 21 Agustus 2013.

Egypt Authorizes Use of Live Ammunition Against Pro-Morsi Protesters. Diakses melalui http:// articies.washingtonpost.com/2013-08-15/world/41412007_1_mohamed-morsi-muslimbrotherhood-rabaa pada tanggal 22 Agustus 2013.

Egypt: Call For Daily Protests As Dozens Die. Diakses melalui http://news.sky.com/ story/1129271/egypt-call-for-daily-protests-as-dozens-die pada tanggal 21 Agustus 2013.

Egypt Deaths Call For Action. Diakses melalui http://news.sky.com/story/1129271/egypt-call-

${ }^{48}$ Horror in Houla. Diakses melalui http://www.economist.com/node/21556237 pada tanggal 22 Agustus 2013.

${ }^{49}$ Rusia \& China Veto Resolusi PBB Soal Suriah, AS Marah. Diakses melalui http://news.detik.com/read/2011/10/05/115906/1737185/11 48/rusia-china-veto-resolusi-pbb-soal-suriah-as-marah pada tanggal 22 Agustus 2013.

50 PBB: Libya Tak Patuhi Resolusi. Diakses melalui http://internasional.kompas.com/read/2011/03/25/10121728/PBB:.Libya.Tak.Patuhi. Resolusi pada tanggal 22 Agustus 2013. 
UNISIA, Vol. XXXIV No. 78 Januari 2013

for-daily-protests-as-dozens-die pada tanggal 21 Agustus 2013.

Egypt's New Interim President: Judge Adly Mansour. Diakses melalui http://english.ahram.org. eg/NewsContent/1/0/75638/Egypt/0/Egypts-new-interim-president-Judge-Adly-Mansour. aspx pada tanggal 21 Agustus 2013.

Elshtein, J. B.. 'Just War and Humanitarian Intervention'. Ideas Vol. 8, No. 2 (2001)

Harris, D. J. Cases and Materials on International Law. London: Sweet and Maxwell. 1991.

Hazem El-Beblawy: Morsi's overall economic performance was weak. Diakses melalui http:/l www.dailynewsegypt.com/2013/06/29/hazem-el-beblawy-morsis-overall-economicperformance-was-weak/ pada tanggal 21 Agustus 2013.

Holzgreve, J. L. dan Robert O. Keohane (ed.) Humanitarian Intervention: Ethical, Legal, and Political Dilemmas. UK: Cambridge University Press. 2003.

Horror in Houla. Diakses melalui http://www.economist.com/node/21556237 pada tanggal 22 Agustus 2013.

Hough, Peter. Understanding Global Security. London: Routledge. 2004.

Ikhwanul Muslimin: Mursi Jadi Tahanan Rumah. Diakses melalui http://www.republika.co.id/ berita/internasional/global/13/07/04/mpdywc-ikhwanul-muslimin-mursi-jadi-tahananrumah pada tanggal 21 Agustus 2013

International Commission on Intervention and State Sovereignty Report, HIm.xi. Diakses melalui http://www.iciss-ciise.gc.ca/pdf/Commission- Report.pdf pada tanggal 22 Agustus 2013.

Islamist Joy as Morsi Morsi Elected Egypt President. Diakses melalui http://www.reuters. com/article/2012/06/24/us-egypt-election-idUSBRE85G01U20120624 pada tanggal 21 Agustus 2013.

Konflik. Mesir dan Indonesia. Diakses melalui http://www.republika.co.id/berita/jurnalismewarga/wacana/13/07/30/mqqkyt-konflik-mesir-dan-indonesia pada tanggal 22 Agustus 2013.

Mauna Boer. Hukum Internasional: Pengertian Peranan dan Fungsi dalam Era Dinamika Global. Edisi Kedua. Cetakan ke-4. Bandung: PT. Alumni. 2011.

Marwah, Onkar. "India's Military Intervention in East Pakistan: 1971-1972". Modern Asian Studies Vol. 13, No. 4 (1979).

Mohammed Morsi reshuffles Egypt's Cabinet, 3 posts go to Muslim Brotherhood. Diakses pada http://www.mcclatchydc.com/2013/05/07/190613/mohammed-morsi-reshuffles-egypts. html\#.UhTUiZWBLOE pada tanggal 21 Agustus 2013.

Moore, Norton John, et.al. Law and Civil War in Modern World. Baltimore: John Hopkins University Press. 1974.

Named Egypt's Winner, Islamist Makes History. Diakses melalui http://www.nytimes. com/2012/06/25/world/middleeast/mohamed-morsi-of-muslim-brotherhood-declared-as- 
Solusi Intervensi Kemanusiaan Sebagai Penyelesaian Konflik ... (Dodik Setiawan N.H) egypts-president.html?pagewanted=all pada tanggal 21 Agustus 2013.

One Year Into Mohamed Morsi's Term Manifold Abuses And The Systematic Undermining of The Rule of Law. Diakses melalui http://www.cihrs.org/?p=6849\&lang=en pada tanggal 21 Agustus 2013.

PBB: Libya Tak Patuhi Resolusi. Diakses melalui http://internasionai.kompas.com/ read/2011/03/25/10121728/PBB:.Libya.Tak.Patuhi.Resolusi pada tanggal 22 Agustus 2013.

Permanasari, Arlina, et.al. Pengantar Hukum Humaniter. Jakarta: ICRC. 1999.

Pemerintah Mesir sebut diplomasi gagal akhiri krisis. Diakses melalui http://www.radioaustralia. net.au/indonesian/2013-08-07/pemerintah-mesir-sebut-diplomasi-gagal-akhirikrisis/1172836 pada tanggal 22 Agustus 2013.

Riedel, Bruce O.. Deadly embrace: Pakistan, America, And The Future Of The Global Jihad. Washington: Brookings Institution Press. 2011

Rome Statute of the International Criminal Court (1998).

Rusia \& China Veto Resolusi PBB Soal Suriah, AS Marah. Diakses melalui http://news.detik. $\mathrm{com} / \mathrm{read} / 2011 / 10 / 05 / 115906 / 1737185 / 1148 /$ rusia-china-veto-resolusi-pbb-soal-suriahas-marah pada tanggal 22 Agustus 2013.

Scachter, Oscar. "The Legality of Pro-Democratic Invasion", 78 American Journal of International Law. 1984.

Situasi Mesir Mencekam, 4 Pendukung Mursi Tewas Bentrok Dengan Polisi. Diakses melalui http://news.detik.com/read/2013/07/04/051742/2292088/1148/situasi-mesir-mencekam4-pendukung-morsi-tewas-bentrok-dengan-polisi pada tanggal 21 Agustus 2013.

The Bloody Intervention In Egypt Was Condemned In A Statement Released By Prime Ministry of Turkey. Diakses melalui http://www.mfa.gov.tr/the-bloody-intervention-in-egypt-wascondemned-in-a-statement-released-by-prime-ministry-of-turkey.en.mfa pada tanggal 21 Agustus 2013.

Timeline of Morsi and Judiciary: One Year in Power. Diakses melalui http://www.dailynewsegypt. com/2013/06/29/timeline-of-morsi-and-the-judiciary-one-year-in-power/ pada tanggal 21 Agustus 2013.

Treaty Between Great Britain, France, and Russia, For The Pacification Of Greece. (London, July 6 , 1827). Diakses melalui http://www.fordham.edu/haisall/mod/1827gktreaty.asp pada tanggal 21 Agustus 2013.

Turkey PM Condemns Inaction On Egypt Crisis. Diakses melalui http://www.channelnewsasia. com/news/world/turkey-pm-condemns/780860.html pada tanggal 21 Agustus 2013.

United Nations Charter 1945 (Piagam Perserikatan Bangsa-Bangsa).

'Vote Rigging' Mars Egypt Election. Diakses melalui http://www.aljazeera.com/news/ middleeast/2010/11/2010112844850659269.html pada tanggal 21 Agustus 2013. 